\title{
Cousineau, Thomas J. An Unwritten Novel: Fernando Pessoa's The Book of Disquiet. London: Dalkey Archive Press, 2013.
}

Bernardo Soares's remark that "anything and everything, depending on how one sees it, is a marvel or a hindrance, an all or nothing, a path or a problem" may serve to illustrate Thomas Cousineau's critical move in his recent book An Unwritten Novel: Fernando Pessoa's The Book of Disquiet. Without departing from major concerns and theoretical trends that have dominated much of pessoano scholarship around The Book of Disquiet since its first edition in 1982, Cousineau's study nevertheless offers a significant change of perspective within this framework, and delivers what it promises: an Ariadne's thread to orient the reader through Pessoa's labyrinthine prose work. The organizing ideas and core argumentation that form this thread provide an original contribution to ongoing scholarship on Pessoa's oeuvre by presenting a reading of The Bookespecially as it emerges in Richard Zenith's edition-as a complexly unwritten/ mutilated modernist novel. Cousineau's able articulation of the modernist literary and critical tradition, along with his insightful close readings, allow him to offer a study of The Book that is not only a welcome corrective-and one that is pleasurable to read-to the emphasis on editorial matters that has saturated much of the recent academic debate on the subject, but which also represents an important resource even to those who might not find his main, totalizing theory entirely convincing. As such, this monograph-the first book specifically focused on The Book of Disquiet to be published in English-is a relevant addition to Pessoa scholarship as well as a necessary study for readers, teachers, students, and researchers of modernism interested in Pessoa's work, whether within or outside the field of Portuguese studies.

Cousineau's complex argumentation may be simplified as follows for the sake of clarity. Soares, a self-described "building in ruins," refuses to follow his contemporaries in responding to modern nostalgia, and the loss of a stable vision of the world and his own place in it, by following any "cult of humanity"-or even by replacing it with that of the superior man; this latter cult he briefly joins but eventually rejects. Instead, he further diminishes his already diminished self throughout the pages of his factless autobiography, turning this 
process of mutilation into a personal predicament. This process, in turn, coexists with an artistic achievement-The Book itself-that, Cousineau argues, emerges, in apparent contrast to Soares's self-proclaimed ruined self, in a greater form of completeness that cannot be attributed to conscious authorial intention. This completeness, the author maintains, mimics at its core Soares's own process of self-dismemberment, for both are predicted in forms of mutilation. More precisely, the completeness of the text emerges from the undoing of the conventional elements of the novel that go unwritten in The Book: setting, plot, character, narration, and the distinction between the protagonist and the author. In unwriting the elements of the novelistic form, Pessoa/Soares-as Cousineau claims, the two are ultimately undistinguishable-eventually paves the way for The Book's greater form of completeness. This completeness arises from the establishment of reciprocities between the various ruins of the novelistic form that make up The Book and a virtual wholeness with which these ruins become interchangeable.

Even those readers (like myself) who may consider Cousineau's attempt at constructing a coherent, totalizing theory of Pessoa's lifelong project not absolutely unproblematic-especially for remaining within a framework that is too dependent both on a homogeneous, disembodied experience of modernity and a metaphysics of centered meaning-will certainly find many relevant comparative approaches and insightful close readings throughout this study. In the first chapter, for example, Cousineau brings to his analysis of The Book's setting Jorge Luis Borges's "The Library of Babel" and Pessoa's construction of Lisbon as a magnificent city in his Lisbon: What Every Tourist Should See (1925). On the one hand, this comparative framing allows the author to sustain his main claims by arguing that the diminished urban setting of Lisbon's commercial center becomes a gateway to the infinite. On the other hand, he also offers many interesting insights concerning Pessoa's Lisbon(s), as well as an original discussion of the textual treatment and questioning of dichotomies such as worth/worthless, high/low, and reality/dream, in several passages of The Book. Such an original comparative approach is also put forward in Cousineau's chapter on plot, in which he draws on Aristotle's notion of plot and Pessoa's theorization and practice of the static drama, as epitomized in his 1913 play The Mariner, to read what he claims to be the rejection of a coherent 
narrative in The Book. This perspective leads the critic to maintain that The Book not only dismantles the Aristotelian notion of plot, but that this mutilation eventually leads to the setting up of a double plot, which, by joining Freud's assertion that death is the goal of life to Mallarmés claim that life's purpose is to become a book, emerges as a locus for the eruption of boundless visions of the ultimate end of things and an aura of timelessness. If Cousineau's attempt to find a coherence in the text-and thus its closure-through a structure of reciprocities and interchangeabilities might be considered problematic due to its totalizing vision, particularly from a perspective informed by contemporary scholarship on modernism, the author's comparative framing nonetheless, and once again, brings an original light to several passages of The Book, particularly those closer to decadent and symbolist aesthetics.

The study's most daring chapter is its last, in which the author discusses The Book in relation to what he defines and terms as the Daedalus complex (which he sees at work from Daedalus myth through Dante's Inferno, Shakespeare's Hamlet, and Eliot's "The Love Song of J. Alfred Prufrock"): a universal artistic desire that starts by impelling the artist into displacing his suffering upon a surrogate and, hereupon, constructing a work that transposes the surrogate's suffering into an aesthetic achievement. According to Cousineau, Pessoa's The Book dismantles this complex by depriving the artist (Pessoa) of his superiority over his surrogate (Soares), in such a way that the creativity of the former and the suffering of the latter become indistinguishable; hence, The Book rejects the novel's traditional distance between writer and character. Furthermore, by eventually failing to complete his book, on which he worked extensively throughout his life, Pessoa has left behind an unwritten masterpiece which ultimately replicates rather than departing from his surrogate's unlived life and diminished self. Cousineau's theorization and readings are an interesting and original contribution to a long-overdue questioning of notions of impersonality in Pessoa's work, as well as a clear stimulus for further thought; nevertheless, one wishes he had pursued his analysis further in the context of Pessoa's text, given that the lion's share of the final chapter is dedicated to the Daedalus complex itself (and how it emerges elsewhere), and only a few last pages are occupied by The Book and its dismantling of this complex. 
Despite these caveats, Cousineau's An Unwritten Novel: Fernando Pessoa's The Book of Disquiet certainly deserves to be widely read, and it can be hoped the Ariadne's thread it attempts to provide will also succeed in bringing more students and scholars of modernism to the labyrinthine world of The Book of Disquiet.

\section{Fernando Beleza}

University of Massachusetts Dartmouth 